\title{
Analysis of The Javan Green Peafowl (Pavo muticus muticus Linnaeus 1758) Habitat in Baluran and Alas Purwo National Park, East Java
}

\author{
Jarwadi Budi Hernowo ${ }^{1 *}$, Cecep Kusmana ${ }^{2}$, Hadi Sukadi Alikodra ${ }^{1}$, Ani Mardiastuti ${ }^{1}$ \\ ${ }^{1}$ Wildlife Ecology and Management Laboratory, Department of Forest Resources Conservation and Ecotourism, Faculty of Forestry, \\ Bogor Agricultural University, Bogor, Indonesia \\ ${ }^{2}$ Forest Ecology laboratory, Department of Silviculture, Faculty of Forestry, Bogor Agricultural University, Bogor, Indonesia
}

\section{ARTICLE INFO}

Article history:

Received June 21, 2017

Received in revised form September 26, 2017

Accepted December 04, 2017

\section{KEYWORDS:}

Habitat,

Analysis,

Javan Green Peafowl,

Baluran,

Alas Purwo.

\begin{abstract}
Information of javan green peafowl habitat is commontly informate as general and only discribing typical habitat used. Details information and data of the componen habitat, availability and function such as (food resources, shelter, cover, drinking site, nesting site, etc), and characteristic function of habitat componen at every habitat type are very important to be known how habitat component support to the javan green peafowl live Baluran and Alas Purwo national park is one of distribution javan green peafowl and it was choosen to study on the habitat analysis. The research was aimed to is to analysis and synthesis of availability, fucntion and characteristic habitat of javan green peafowl and to descripbe of ideal habitat for javan green peafowl. Vegetation analysis was used as method approach to obtain composition, structure of vegetation and potential food, shelter, cover and nesting site. Base on activities of the bird and combaining with use of habitat component, analysis of habitat used was done. The result showed that javan green peafowl get food at open area and feed much on grasses and shrubs.Drinking site is areal where water available contiously. The characteristic of feeding site is open area which is growth by grasses and shrubs. The shelter sites were used by the birds such as trees or ground bellow trees where are closed to feeding site. Characteristic roosting site is tall trees (emergent trees), the leaves are not dense, rather open, the branches of the trees form a relatively upright angle to the stem, and not far from the trees present the open area. The green peafowl select nest places at open area which is grow by shrubs and put the eggs at the ground. The ideally habitat of the javan green peafowl composed by open area which is growing by grasses and shrubs as feeding site, places where water resources available as drinking site, tree or shaded places as sheltering and resting site, tree, forest or dense shrubs for covering/refuge site, dust places for dusting activities, open area for dancing and open area which is growing by shrubs for nested places were compound closed each other.
\end{abstract}

\section{Introduction}

The javan green peafowl status is protected bird in Indonesia base on SK Mentan No 66/Kpts/Um/2/1973 dan Peraturan Pemerintah Republik Indonesia No 7 tahun 1999. According to ICBP (The International Council for Bird Preservation) has stated that the green peafowl as globally threatened bird in both population and their habitat (Collar and Andrew1988). Meanwhile CITES has recorded in Appendix II and IUCN Red List 2016 has categorized as endangered bird.

\footnotetext{
* Corresponding Author.

E-mail Address: jblina11@yahoo.com
}

The javan green peafowl (Pavo muticus muticus) has distributed at several habitat types such as; tropical low land forest, monsoon forest, savanna, and teak forest. The range of green peafowl has become patchily and locally restricted in every site of their local distribution. Nowadays, possible habitats to support these birds are forest reserves (national park, game reserve, nature reserve, and forest protected area) and teak plantation area (Hernowo 1995). The distribution of javan green peafowl only in java island and as macro landscape in Java is at fragmented, restricted and isolated habitat.

Baluran and Alas Purwo national park are as one site of javan green peafowl distribution at tip of the 
Eastern part of Java Island. Baluran national park have typically savanna and monsoon forest habitat, but Alas Purwo have habitat type more diverse like; low land tropical rain forest, grazing area, and teak plantation with intercropping (Hernowo et al. 2011). In relation with the habitat types, densities of the birds have differences. Hernowo (1999) give an example at Baluran national park that the green peafowl more abundant at habitat type of savanna-monsoon forest compared the other habitat type. Hernowo and Hernawan (2003) recorded that the green peafowl at teak forest plantation KPH Sumedang more abundant at bordered between intercropping areas with teak plantation age class IV.

Information of javan green peafowl habitat is commontly informate as general and only discribing typical habitat used (Mulyana 1988; Setiawan 1994; Setiadi 1994; Hernowo 1995; van Balen et al. 1995; Brickle 2002; Rini 2005; Septania 2009; Takandjandji and Sawitri 2011). But the analyzing on detail of whole availability, charachteristic and function of javan green peafowl habitat is not yet been done. Details information and data of the componen habitat, availability and function such as (food resources, shelter, cover, drinking site, nesting site, etc), and characteristic function of habitat componen at every habitat type are very important to be known how habitat component support to the javan green peafowl live. Focus observation on collecting data and information of availability, function and characteristic of javan green peafowl habitat component should be done exactly and analyzed properly. Result from analysis fucntion and characteristic of habitat component will get composition and structure of ideal habitat of the javan green peafowl.
The aim of this paper is to analysis and synthesis of availability, fucntion and characteristic habitat of javan green peafowl and to descripbe of ideal habitat for javan green peafowl.

\section{Materials and Methods}

Research was conducted at Baluran and Alas Purwo national park, June 2006 until December 2007, March 2009, March 2010, April 2012, April 2013. The sample area was focused at savanna, beach forest and monsoon forest of Bekol resort in Baluran national park, and Sadengan grazing area, intercropping area and teak plantation of Rowobendo resort in Alas Purwo national park.

The sample area for analysis javan green peafowl habitat in BNP, cover an area of about $4 \times 3 \mathrm{~km}$ (1,200 ha) which have four main type of habitat like; savanna, beach forest, evergreen forest and monsoon forest. In each type of javan green peafowl habitat was made continous transect to get composition and structure of vegetation (Figure 1). Besides that analyzed, additional observation was done at water holes, roosting site and feeding site to know function of habitat for supporting javan green peafowl live.

Analysis javan green peafowl habitat in APNP was focused at five places such as Sadengan grazing area, Rowobendo intercropping area, Guntingan intercropping area, Sumbergedang teak plantation forest, and Ngagelan teak plantation forest. That area has representative on javan green peafowl habitat in APNP (Figure 2). The sample area cover around ( $3 \mathrm{x}$ $4 \mathrm{~km})$.
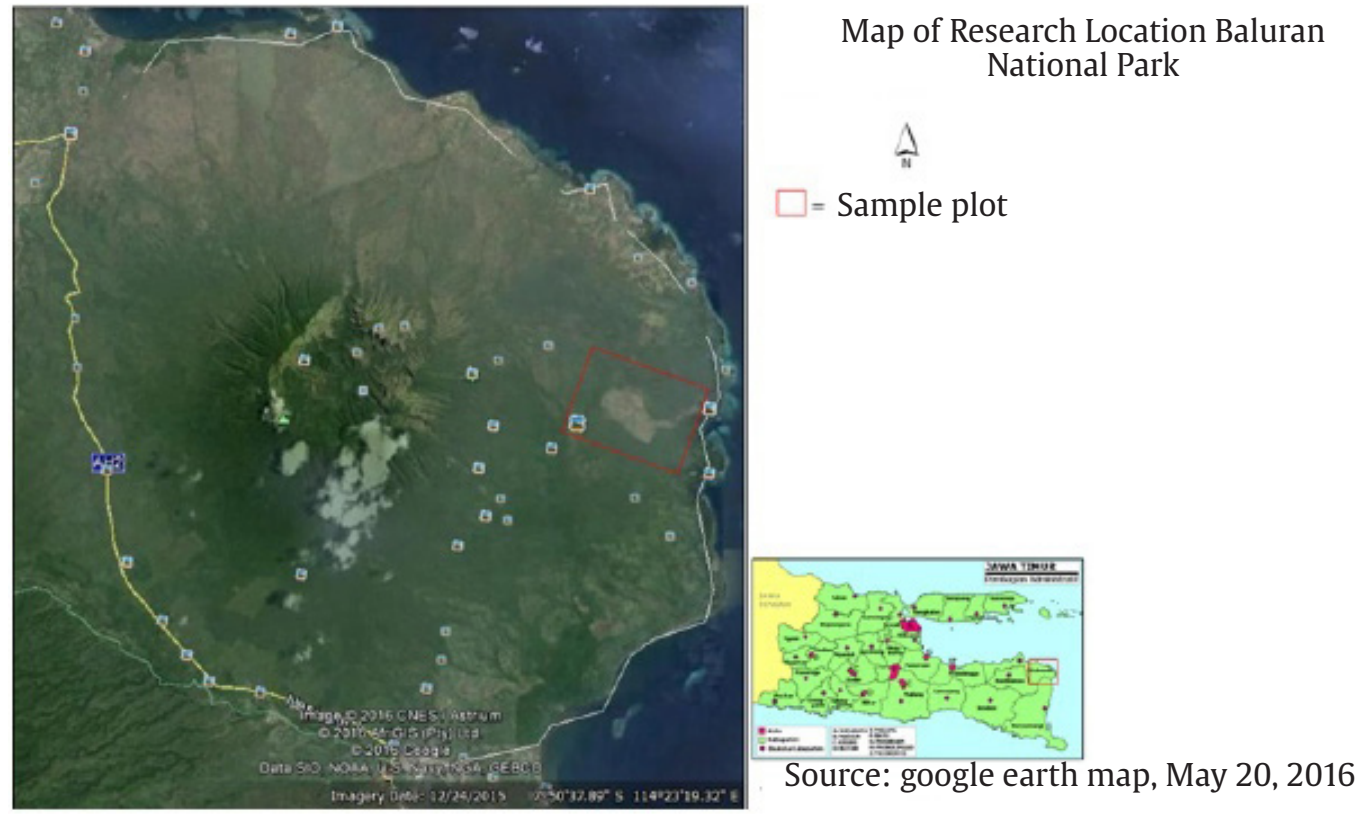

Figure 1. Map of Baluran National Park (sources google earth,12/24/2015) 

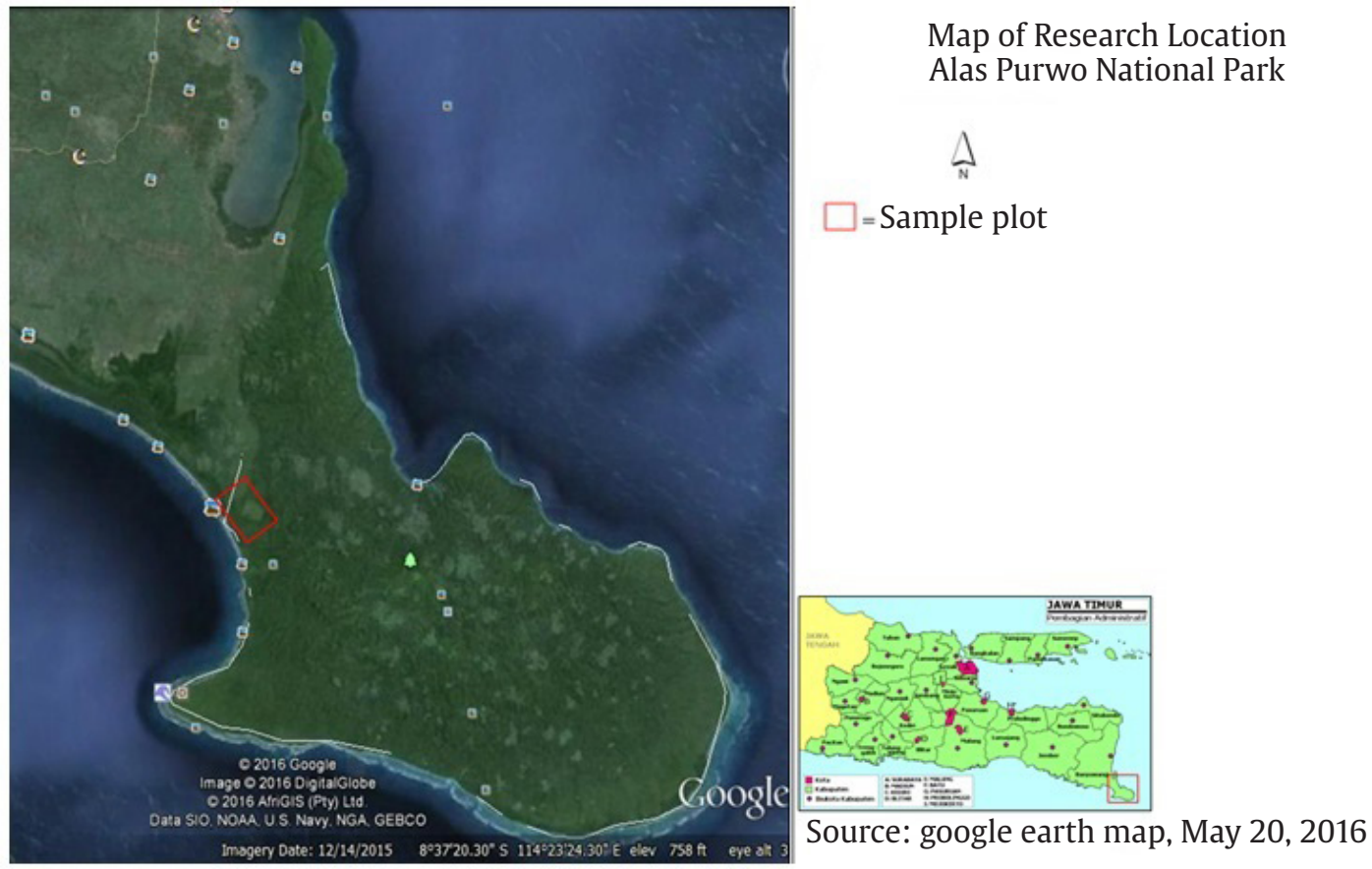

Figure 2. Map of Alas Purwo National Park (sources google earth,12/24/2015)

The green peafowl habitat was described by vegetation analyzed approach. For data analysis, quantitative value of vegetation was used to describe composition and structure vegetation at each type of habitat. It was analyzed using the important index value (IVI) method after Mueller and Ellenberg (1974) as follows:

where:

$$
\mathrm{IVI}=\mathrm{RF}+\mathrm{RD}+\mathrm{RDo}
$$

$\mathrm{RF}=$ Relative Frequency

$\mathrm{RD}=$ Relative Density

$\mathrm{RDo}=$ Relative Dominance

Data were collected from trees, poles and sapling is: species, number, dbh (diameter at breast height) and height. Meanwhile for seedling only described: number and species. The sample plot (Transect with number of each plot 30 , size plot $20 \times 20 \mathrm{~m}$ for tree, $10 \times 10 \mathrm{~m}$ for poles, $5 \times 5 \mathrm{~m}$ for sapling). The species and number of herbs, shrubs and grasses were also recorded in sample plot with size $1 \mathrm{x} 1 \mathrm{~m}$, number of plot 30 in each habitat type.

To describe feeding site, roost sites and disply area used by green peafowl direct observation was done and its recorded such as: species of vegetation, number and frequencies of used and some of habitat characteristics condition. To know vegetation function at green peafowl habitat (feeding sites, roosting sites, covering sites and sheltering sites) was analyzed by percentage of habitat used or duration using at each habitat types with the formula as follow:
Where:

$$
\mathrm{Fh}=\mathrm{F} / \mathrm{TF}
$$

Fh $=$ Function of green peafowl habitat like for feeding area, roosting sites, covering sites and sheltering sites base onfrequency or duration,

$\mathrm{F}=$ =Frequencies green peafowl using function of habitat,

TF =Total Frequencies green peafowl using function of habitat,

Hypothesis

Ho $=$ The green peafowl does not prefer to certain habitat,

$\mathrm{H} 1 \neq$ The green peafowl prefer to certain habitat

$$
\chi^{2}=\Sigma(|\mathrm{O}-\mathrm{E}|-0.5)^{2} / \mathrm{E}
$$

$\mathrm{O}=$ Individual number were observed

$\mathrm{E}=$ Individual number were expected

Test criteria

$\chi^{2}$ calculation $>\chi^{2}$ table $\rightarrow$ reject Ho

$\chi^{2}$ calculation $<\chi^{2}$ table $\rightarrow$ accept $\mathrm{Ho}$

To describe charateristic of habitat component fucntion for the green peafowl used descriptive analysis. The maint parameter is especially character of habitat component such as availability, unique of habitat condition, prefferable, frequently, long time and number used.

To describe habitat ideal was analyzed of uniqueness (characteristic) of each habitat component which perform in one unit habitat base on availability, 
frequently, duration, and preferable than synthesis of total characteristic of habitat component (food, water, shelter, cover, roosting site, nesting site). Criteria used in habitat ideal is synthesis of habitat component, (a) Availability, (b) Function, (c) Characteristic.

\section{Result}

\subsection{Habitat Used by the Javan Green Peafowl}

The javan green pefowl in BNP used several habitat types at Bekol Resort such as savanna, monsoon forest, evergreen forest, and beach forest. But the birds abundances at each habitat types were differ. The birds were more prefer used savanna habitat type compared with the other habitat types such as monsoon forest and beach forest. That condition has indicated by individual number of the javan green peafowl much higher at savanna than individual number for other habitat type (Figure 3 ).

The habitat type has been used by the javan green peafowl at Rowobendo Resort APNP were lowland tropical rain forest and grazing area, intercropping area with teak plantation forest, beach forest and teak plantataion forest. The bird abundances at each habitat types were differ. That condition was related with preferences of the javan green peafowl to habitat type. The habitat types were preffered by the javab green peafowl in APNP was Grazing area Sadengan which surround by low land tropical rain forest and intercropping area in teak plantation of Gunting. That condition has indicated by individual number of the javan green peafowl much higher at those habitat types (Figure 4 ).

Base on field observation, that the javan green peafowl in BNP and APNP used several habitat types, but concentred (central distribution) at open area, which the area not too large ( $<20$ ha), not far from the open area present trees as roosting site. The trees were as clumped or individual, event forest. The open area was growed by grasses and

Several Type of Habitat used by Javan Green Peafowl related to Individuals Number of the Bird In Baluran National Park

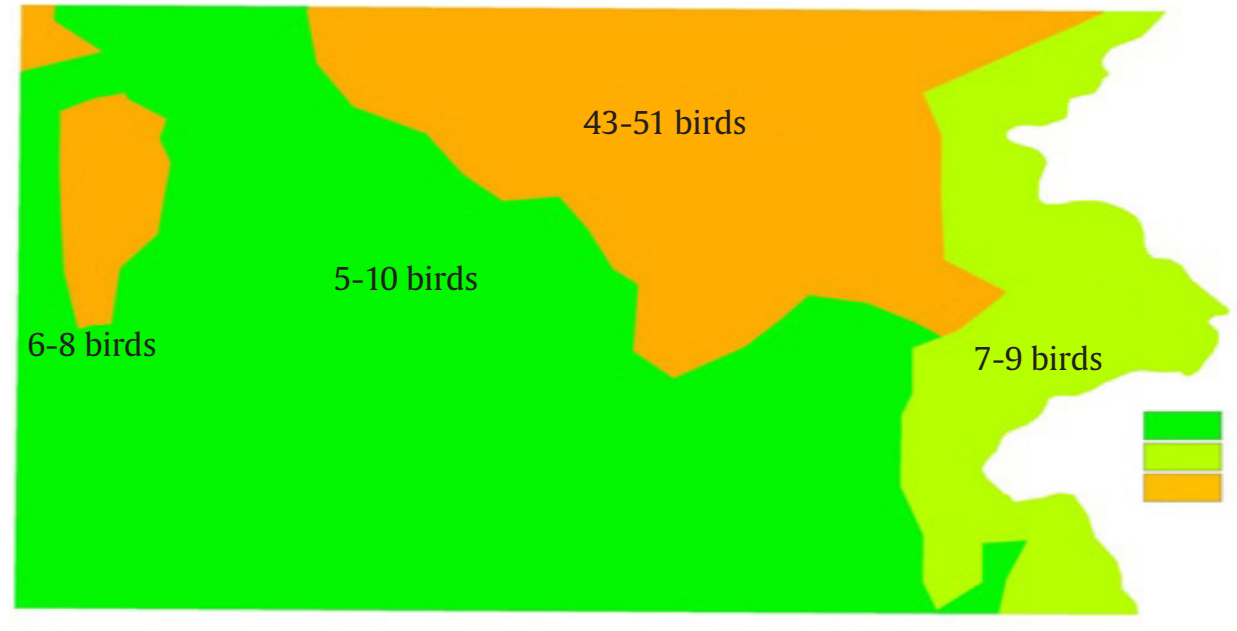

Monsoon Forest

Beach Forest and Mangrove

Savanna

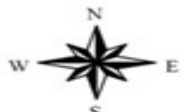

Figure 3. The habitat type in relation to population abundance of the javan green peatowl in BNP

Several Type of Habitat used by Javan Green Peafowl related to Individuals Number of the Bird In Alas Purwo National Park

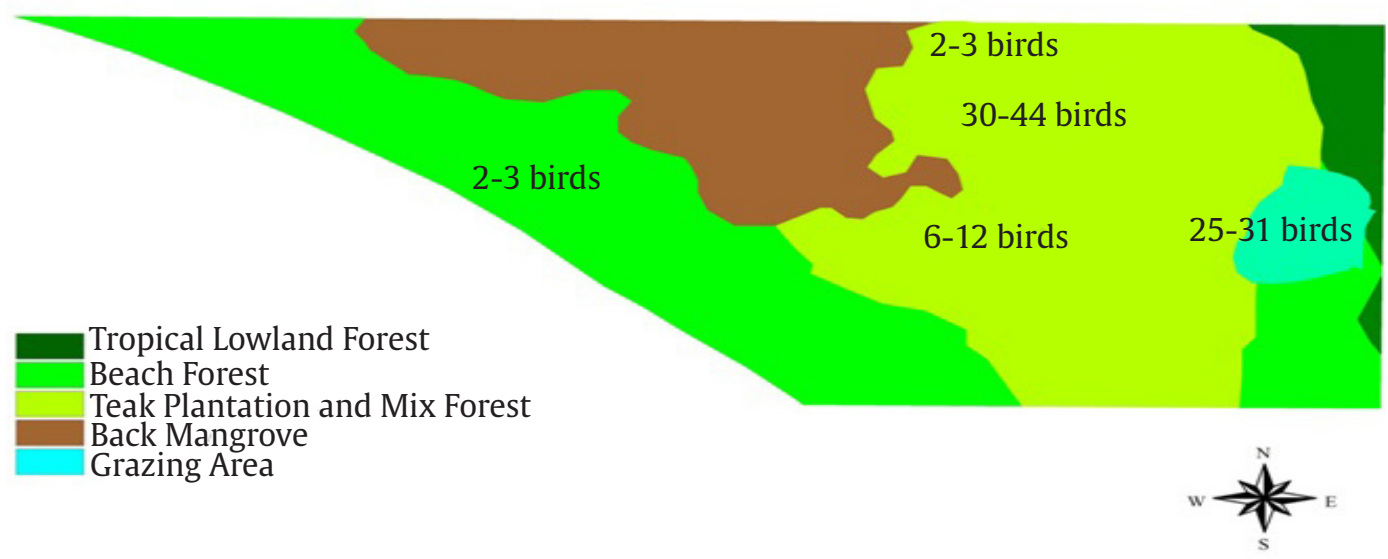

Figure 4. The habitat type in relation to population abundance of the javan green peafowl in APNP 
shrubs. The habitat types which have open area, roost tree and available water resources for drink the javan green peafowl in BNP was savanna habitat type, meanwhile in APNP the habitat which have like mentioned above were Sadengan grazing area which surround by lowland tropical rain forest and intercropping area in teak plantation of Gunting.

Gradient of the javan green peafowl habitat at BNP and APNP was expressed by used of habitat component by the javan green peafowl. The javan green peafowl used open area which is growed by grasses and shrubs as feeding site, open area which is growed by shrubs was used by nesting site, forest or dense shubs area were used by the birds as covering site and shading trees or egde of forest is used as shaltering site. Clean places are used as dancing area for the male bird. Certain trees which are closed to open area used as roosting site. Available of water resources at the habitat type influenced on presented of the javan green peafowl.

\subsection{Feeding Site at APNP and BNP}

The javan green peafowl select open area which dominated by grasses at several habitat types in both national park Alas Purwo and Baluran as feeding site. In APNP, the bird frequently feed in sadengan grazing area. Sadengan grazing area is a man made, which the former was lowland tropical rain forest (TRF), it opened and planted several grasses and the large area was approximately 60 ha. Intercropping area at resort Rowobendo APNP is one habitat types which is used by the javan green peafowl as feeding site. In intercropping area was growed by grasses and shrubs. The grass and shrubs composition was recorded from sample area in Sadengan grazing area, intercropping area, and teak plantation at Table 1.

Species grass which is dominant in Sadengan grazing area were lamuran/java grass (Polytrias amaura), tekirawa/coco grass (Cyperus rotundus) and paitan/buffalo grass (Paspalum conjugatum). But

Table 1. Vegetation analysis result of food resources of the javan green peafowl at several habitat types in APNP

\begin{tabular}{|c|c|c|c|c|c|c|c|c|c|c|}
\hline \multirow{3}{*}{ Vegetation species } & \multicolumn{10}{|c|}{ Habitat type } \\
\hline & \multicolumn{2}{|c|}{$\begin{array}{l}\text { Sadengan } \\
\text { grazing area }\end{array}$} & \multicolumn{2}{|c|}{$\begin{array}{c}\text { Rowobendo } \\
\text { intercropping area }\end{array}$} & \multicolumn{2}{|c|}{$\begin{array}{c}\text { Gunting } \\
\text { intercropping area }\end{array}$} & \multicolumn{2}{|c|}{$\begin{array}{l}\text { Sumber gedang } \\
\text { teak plantation }\end{array}$} & \multicolumn{2}{|c|}{$\begin{array}{c}\text { Ngagelan teak } \\
\text { plantation }\end{array}$} \\
\hline & DR & FR & DR & FR & DR & FR & DR & FR & DR & FR \\
\hline Paspalum conjugatum & 32 & 0.63 & 12 & 0.3 & 20 & 0.5 & 8 & 0.2 & 8 & 0.2 \\
\hline Cyperus rotundus & 38 & 0.73 & 16 & 0.2 & 24 & 0.6 & 10 & 0.3 & 8 & 0.2 \\
\hline Ischaemum timorense & 28 & 0.33 & & & & & & & & \\
\hline Axonopus compresus & 22 & 0.46 & 8 & 0.2 & 16 & 0.2 & 9 & 0.2 & 7 & 0.2 \\
\hline Polytrias amaura & 30 & 0.46 & 10 & 0.2 & 16 & 0.7 & 6 & 0.1 & & \\
\hline Brachiaria mutica & 22 & 0.33 & 8 & 0.2 & 14 & 0.3 & 6 & 0.1 & & \\
\hline Euleusine indica & 20 & 0.33 & & & 10 & 0.3 & 6 & 0.2 & 5 & 0.2 \\
\hline Dactyloctenium aegyptium & 18 & 0.43 & & & & & & & & \\
\hline Cyonodon dactylon & 20 & 0.36 & 10 & 0.2 & 12 & 0.2 & & & & \\
\hline Andropogon aciculatus & 30 & 0.33 & & & & & & & & \\
\hline Echinocloa colona & 16 & 0.26 & & & & & & & & \\
\hline Panicum stagnitium & 8 & 0.16 & & & & & & & & \\
\hline Panicum crusgalli & 8 & 0.16 & & & & & & & & \\
\hline Optimenus broimanii & 12 & 0.23 & & & & & & & & \\
\hline Centrella asiatica & 10 & 0.16 & & & & & & & & \\
\hline Sida acuta & 8 & 0.63 & 6 & 0.2 & 8 & 0.2 & 4 & 0.1 & & \\
\hline Mikania micrantha & 4 & 0.16 & & & 2 & 0.2 & & & & \\
\hline Ageratum conyzoides & 18 & 0.26 & 8 & 0.3 & 10 & 0.3 & 6 & 0.1 & 4 & 0.1 \\
\hline Amaranthus spinosus & 10 & 0.23 & & & 4 & 0.2 & & & & \\
\hline Phyllanthus niruri & 18 & 0.43 & 10 & 0.3 & 12 & 0.3 & & & & \\
\hline Euphorbia hirta & 6 & 0.16 & & & & & & & & \\
\hline Eupathorium odoratum & 20 & 0.36 & & & & & & & & \\
\hline Cassia tora & 30 & 0.5 & & & & & & & & \\
\hline Fassiflora foetida & 12 & 0.3 & & & & & & & & \\
\hline Glycine max & & & & & 30 & 0.3 & & & & \\
\hline Zea mays & & & & & 4 & 0.3 & & & & \\
\hline Capsium frutescens & & & & & 9 & 0.3 & & & & \\
\hline Arachis hypogea & & & & & 25 & 0.3 & & & & \\
\hline Vigna sinensis & & & & & 9 & 0.3 & & & & \\
\hline Phaseolus radiatus & & & & & 9 & 0.3 & & & & \\
\hline
\end{tabular}

Remark: DR = density relative (\%), FR= frequency relatiive (\%) 
shrubs species which are dominant such as encengenceng/ring worm plant (Cassia tora) and kirinyuh/ siam weed (Eupathorium odoratum). The Grasses and Shrubs species are prefer such as lamuran/ java grass (Polytrias amaura), paitan/buffalo grass (Paspalum conjugatum), kolonjono/para grass (Brachiaria mutica), tekirawa/coco grass (Cyperus rotundus), sidaguri/common wireweed (Sida acuta), and bayeman/spiny amaranth (Amaranthus spinosus).

The javan green peafowl feed more concentred in savanna Bekol BNP, most of the area composed by open area which growed by grasses and shrubs. The bird feed on grasses and shrubs, that food more available during dry season compared other habitat types. The grasses and shrubs species which are recorded at sample plot in savanna, beach forest, monsoon forest and evergreen forest habitat types (Table 2).

The javan green peafowl is 0mnivorous bird, but main of the javan green peafowl food was grasses and shrubs. The birds feed on seed, fruit, flower, and the leaf of grasses and shrubs. The javan green peafowl is opportunistic bird. The bird used chance (opportunate) on abundances available of food. The availability of food in BNP and APNP were influenced by the season. In general, the food more available at rainy season compared with dry season. The kind of food which is eaten by peafowl was recorded both in APNP and BNP at Table 3 .

Table 2. Vegetation analysis result of food resources of the javan green peafowl at several habitat types in BNP

\begin{tabular}{|c|c|c|c|c|c|c|c|c|}
\hline \multirow{3}{*}{ Vegetation species } & \multicolumn{8}{|c|}{ Habitat type } \\
\hline & \multicolumn{2}{|c|}{ Savana } & \multicolumn{2}{|c|}{ Beach forest } & \multicolumn{2}{|c|}{ Monsoon forest } & \multicolumn{2}{|c|}{ Evergreen forest } \\
\hline & & $\mathrm{F}$ & $\mathrm{D}$ & $\mathrm{F}$ & $\mathrm{D}$ & $\mathrm{F}$ & $\mathrm{D}$ & 0.3 \\
\hline Abutilon cripum & 30 & 0.76 & 14 & 0.3 & 22 & 0.3 & 12 & 0.2 \\
\hline Ocmum amaricanum & 25 & 0.46 & 12 & 0.2 & 18 & 0.3 & 9 & 0.2 \\
\hline Vernonia cinerea & 25 & 0.43 & 8 & 0.2 & & & 7 & 0.2 \\
\hline Barleria prionithis & & & & & 8 & 0.2 & 5 & 0.3 \\
\hline Stachyrtapeta jamaicensis & 20 & 0.76 & 10 & 0.5 & 14 & 0.4 & 8 & \\
\hline Thespesia lampas & 18 & 0.43 & 12 & 0.3 & 10 & 0.2 & & \\
\hline Amaranthus spinosus & 8 & 0.33 & & & & & & 02 \\
\hline Callotropis gigantea & 5 & 0.16 & 3 & 0.2 & & & & 0.2 \\
\hline Capparis separia & & & 2 & 0.2 & 2 & 0.2 & 2 & 02 \\
\hline Ipomoea obscura & 4 & 0.13 & & & & & & \\
\hline Acalypha indica & 12 & 0.36 & & & 4 & 0.3 & 4 & \\
\hline Euphorbia hirta & 8 & 0.16 & & & & & & 0.2 \\
\hline Phyllanthus niruri & 17 & 0.56 & & & & & & \\
\hline Bauhinia angulata & & & & & 2 & 0.2 & 2 & \\
\hline Cassia mimosoides & & & & & 4 & 0.2 & & \\
\hline Cassia obtusifolia & 3 & 0.16 & & & & & & \\
\hline Clitoria ternatea & 7 & 0.16 & & & 5 & 0.3 & & \\
\hline Flemingia lineata & 9 & 0.2 & & & & & & \\
\hline $\begin{array}{l}\text { Indigofera sumatrana } \\
\text { Tephrosia pumila }\end{array}$ & $\begin{array}{r}16 \\
3\end{array}$ & $\begin{array}{l}0.36 \\
0.16\end{array}$ & & & 10 & 0.3 & & 0.3 \\
\hline Sida acuta & 14 & 0.5 & 6 & 0.4 & 8 & 0.4 & 4 & 0,03 \\
\hline Wisadula acidula & 4 & 0.16 & & & & & & 0.03 \\
\hline Streblus asper & & & & 0.03 & & 0.03 & & 0.2 \\
\hline Corypha utan & & & & & & & & 0.2 \\
\hline Passiflora foetida & 6 & 0.3 & & & 4 & 0.3 & 2 & 0.2 \\
\hline Plumbago zeylanica & 2 & 0.13 & & & & & 2 & \\
\hline Glucosmis cochinchinensis & 4 & 0.36 & & & 4 & 0.2 & 4 & 0.3 \\
\hline Zyzyphus rotundifolia & 2 & 0.2 & & & 2 & 0.2 & & 02 \\
\hline Morinda tinctoria & & & & & & & 2 & \\
\hline Azima sarmentosa & 3 & 0.33 & & & & & 2 & \\
\hline Mimosa pudica & 4 & 0.3 & 2 & 0.2 & 4 & 0.2 & & \\
\hline Ageratum conyzoides & 11 & 0.2 & & & & & & 0.2 \\
\hline Eleucine indica & 15 & 0.4 & & & 12 & 0.3 & & \\
\hline Cynodon dactylon & 22 & 0.4 & & & 12 & 0.3 & 8 & \\
\hline Cyperus rotundus & 32 & 0.36 & 12 & 0.2 & & & & \\
\hline Paspalum conjugatum & 30 & 0.33 & & & 12 & 0.2 & & 0.2 \\
\hline Polytrias amaura & 42 & 0.4 & 12 & 0.2 & & & 8 & \\
\hline Brachiaria mutica & 28 & 0.3 & & & & & 8 & \\
\hline Andropogon aciculatus & 13 & 0.2 & 16 & 0.2 & & & & \\
\hline Optimenus broimanii & 16 & 0.16 & & & & & & \\
\hline Dactylocteniun aegyptium & 14 & 0.2 & & & & & & \\
\hline
\end{tabular}

Noted $\mathrm{D}=$ density (ind $\left./ \mathrm{m}^{2}\right), \mathrm{F}=$ Frequency $(\%)$ 
Many kind of grasses and shrubs species (36 species), Trees and palm (6 species), and holticulture plant ( 6 species) which are eaten by the javan green peafowl. The food variation of the javan green peafowl in BNP was quite higher than APNP (Figure 5). The most of their diets were got from open area at each habitat types in the both national park (Table 4).

Chi-square test for abundancies of food resources at several types of habitat of BNP and APNP showed that densities of grass species and shrubs which are eaten by javan green peafowl significant different, BNP $\left(\chi^{2}=1619.149, \mathrm{P}<0.01\right)$ and $\operatorname{APNP}\left(\chi^{2}=1744.099, \mathrm{P}<0.01\right)$.

\subsection{Drinking Site}

Water is important factor of habitat component of the javan green peafowl living. The green peafowl come to drinking site in Sadengan APNP is man made water reservoir, or a puddle where filed up by water which distributed in the grazing area or Sadengan river. Sprinkler water as tool to distributed water for grasses, but saturated water filed up the puddle. The puddle as drinking site for the peafowl was formed from foot track of big mammal like Banteng (Bos javanicus) and Rusa Deer (Cervus timorensis). The javan green peafowl which is present at intercropping area get water from drainage and mangrove area. During the dry season water in Sadengan grazing area only available at sprinkler area and man made water reservoir, but Sadengan river was not available.

During the dry season in BNP the condition became very harsh. The rainfall is quite low nearly $7-8$ months are dry. The water is limited and only available in certain places. At sample area, water is available in Bekol, Bama, Kelor and Manting, but in the rainy season water is available everywhere.

The frequency of the bird drink has been recorded base on observation time in APNP and BNP as recorded at Table 5.

\subsection{Sheltering Site and Resting Area}

After the temperature was approximately 28$29^{\circ} \mathrm{C}$, the day became hot, the javan green peafowl used shelter site under trees, at trees or in shrubs and bushes. The trees are used by the peafowl at middle of sadengan grazing area APNP, like walikukun (Schoutenia ovata), laban (Vitex sp.), and sonokeling (Dalbergia latifolia). The green peafowl sheltering while take rest. Besides those trees, the bird used other trees for sheltering and resting such as apak (Ficus infectoria), serut (Strepblus asper), and Bamboo (Bambusa sp.) where they present at edge of sadengan grazing area. Meanwhile in BNP, the birds sheltered and rest under widoro bukol (Zyzyphus rotundifolia), mimba (Azadirachta indica), asem (Tamarindus indica), pilang (Acacia leucophloea), kesambi (Schleichera oleosa), herbs and shrubs. The frequency of sheltering and resting of javan green peafowl APNP and BNP as shown at Table 6.

The green peafowl will sheltered under luxuriant trees or climbed up and stay at middle crown of trees or at shrubs and bushes. For sheltering and resting the birds will select on certain criteria such as luxuriant trees, dense shrubs and bushes also save from any disturbance during they are sheltering and resting. The peafowls will shelters during hot days (09.00 am - $14.00 \mathrm{pm}$ ). Chi-square test for frequently the javan green peafowl used sheltering trees at several types of habitat of BNP and APNP showed that frequencies of using sheltering trees has significant different in BNP $\left(\chi^{2}=681.7967, \mathrm{P}<0.01\right)$ but for APNP do not significant $\left(\chi^{2}=28.86, \mathrm{P}>001\right)$.

\subsection{Covering Site (Refuge)}

The javan green peafowl used forest or shrubs as covering site (refuge). Covering site have function as protected places from several disturbances which threat to the bird. Choosing places for covering (refuge) depend on kind of disturbance and availability of covering site.

Chi-square test for frequently the javan green peafowl used covering (refuge) at several types of habitat of BNP and APNP showed that frequencies of covering has significant different in both BNP and APNP, BNP $\left(\chi^{2}=185.4376, \mathrm{P}<0.01\right)$, and APNP $\left(\chi^{2}=\right.$ $404.3685, \mathrm{P}<0.01)$. The javan green peafowl freqeuncy of covering in APNP and BNP as recorded at Table 7.

\subsection{Roosting Site}

Not every tree is used by the green peafowl as roosting site, and they will select on certain trees. Several trees were used by the birds as roosting site in Sadengan APNP such as Randu alas (Bombax valetoni), Bendo (Artocarpus elastica), Apak (Ficus invectoria), Jambu hutan (Syzigium samarangense), Laban (Vitex pubescens), and Gempol (Nauclea siamea). The javan green peafowl frequency using tree as roosting site in APNP as shown at Table 8.

The number of birds using a roost tree varies over the year. In one roost tree never used by 2 adult male. Between adult males have distance mechanism each other (Hernowo et al. 2011b). Number of female bird roost together with male also varies over the year.

Base on the trees were chosen as roosting site by the green peafowl in savanna BNP, it were recorded at table 9. Preferred trees as roosting site in BNP are Pilang and Gebang trees. The tree was selected by the bird the emergent tree with crown not so dense the leave.

The characteristic of roosting trees has similar to (Hernowo 1995; Hernowo 1999; Hernowo et al. 2011b) such as, (a) The trees are tall or emergent trees; (b) Close to the roosting tree present open area; (c) The branches of the trees relatively upright angle to the 
Table 3. Vegetation species which are eaten by the javan green peafowl in Sadengan grazing area and intercropping of teak plantation of APNP and savanna also monsoon forest of BNP

\begin{tabular}{|c|c|c|c|c|c|}
\hline Species vegetation & Local name & Common name & Lifeform & Part of vegetation are eaten & Location \\
\hline Claome rutidosperma & Bohbohan & $\begin{array}{l}\text { Consumption } \\
\text { weed }\end{array}$ & Grasses & Leaf, Flower, Seed & APNP \\
\hline $\begin{array}{l}\text { Paspalum } \\
\text { conjugatum }^{* *}\end{array}$ & Pahitan & Buffalo grass & Grasses & Leaf, Flower, Seed & APNP, BNP \\
\hline Cyperus rotundus** & Teki & Coco grass & Grasses & Leaf, Flower, Seed & APNP, BNP \\
\hline Ischaemum timorense & Bangbangan & Lucuntu grass & Grasses & Leaf, Flower, Seed & APNP, BNP \\
\hline Axonopus compresus & Putihan & Carpet grass & Grasses & Leaf, Flower, Seed & APNP, BNP \\
\hline Polytrias amaura & Lamuran & Java grass & Grasses & Leaf, Flower, Seed & APNP, BNP \\
\hline Brachiaria mutica & Kolonjono & Para grass & Grasses & Leaf, Flower, Seed & APNP, BNP \\
\hline Euleusine indica & Lulangan & Wire grass & Grasses & Leaf, Flower, Seed & APNP, BNP \\
\hline $\begin{array}{l}\text { Dactyloctenium } \\
\text { aegyptium }\end{array}$ & Katelan & Bahama grass & Grasses & Leaf, Flower, Seed & APNP, BNP \\
\hline Cyonodon dactylon & Kerawatan & Bermuda grass & Grasses & Leaf, Flower, Seed & APNP, BNP \\
\hline $\begin{array}{l}\text { Andropogon } \\
\text { aciculatus }\end{array}$ & Domdoman & Love grass & Grasses & Leaf, Flower, Seed & APNP, BNP \\
\hline Echinocloa colona & Tuton & Jungle rice grass & Grasses & Leaf, Flower, Seed & APNP, BNP \\
\hline Panicum stagnitium & Jawen & 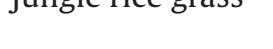 & Grasses & Leaf, Flower, Seed & APNP, BNP \\
\hline Panicum crusgalli & Kejawen & Barnyard grass & Grasses & Leaf, Flower, Seed & APNP, BNP \\
\hline Optimenus broimanii & Rayapan & Francais grass & Grasses & Leaf, Flower, Seed & APNP, BNP \\
\hline Althernanthera & Kremah & Aligator weed & & & \\
\hline phyloxeroides & & & Grasses & Leaf, Flower, Seed & APNP, BNP \\
\hline Centrella asiatica & Pegagan & Asiatic penywort & Grasses & Leaf, Flower, Seed & APNP, BNP \\
\hline $\begin{array}{l}\text { Pseudoranthenum } \\
\text { diversifolium }\end{array}$ & Kaki kambing & The Blue pansy & Grasses & Leaf, Flower, Seed & APNP, BNP \\
\hline Sida acuta** & Sidaguri & $\begin{array}{l}\text { common } \\
\text { wireweed }\end{array}$ & Shrubs & Leaf, Seed & APNP, BNP \\
\hline Mikania micrantha & Uwi-uwian & $\begin{array}{l}\text { Mile-a-minute } \\
\text { weed }\end{array}$ & Shrubs & Leaf, Flower & APNP, BNP \\
\hline Ageratum conyzoides & Wedusan & Billy goat weed & Shrubs & Flower, Seed & APNP, BNP \\
\hline Amaranthus spinosus & Bayam duri & Spiny amaranth & & & \\
\hline Phyllanthus niruri** & Meniran & Gale of wind & Shrubs & Leaf, Flower, Seed & APNP, BNP \\
\hline Euphorbia hirta & Patikan Kebo & Pill-bearing & Shrubs & Leaf, Flower, Seed & APNP, BNP \\
\hline & & spur & Shrubs & Leaf, Flower, Seed & APNP, BNP \\
\hline Fassiflora foetida & Santiet & $\begin{array}{l}\text { Stinking } \\
\text { passionflower }\end{array}$ & Shrubs & Leaf, Flower, Seed & APNP, BNP \\
\hline $\begin{array}{l}\text { Eupathorium } \\
\text { odoratum }\end{array}$ & Kirinyuh & Siam weed & Shrubs & Leaf, Flower & APNP, BNP \\
\hline $\begin{array}{l}\text { Stachyrtapeta } \\
\text { jamaicensis* }\end{array}$ & Jarong & Blue porterweed & Shrubs & Leaf, Flower, Seed & APNP, BNP \\
\hline Cassia tora & Orok-orok & Sickle senna & Shrubs & Leaf, Flower, Seed & APNP, BNP \\
\hline Glycine max & Kedelai & Soybean & Horticulture & Leaf, Fruit & APNP \\
\hline Zea mays & Jagung & Maize & Horticulture & Leaf, Fruit & APNP \\
\hline Capsium frutescens & Cabe rawit & Red pepper & Horticulture & Leaf, Fruit & APNP \\
\hline Arachis hypogea & Kacang tanah & Peanut & Horticulture & Leaf, Fruit & APNP \\
\hline Vigna sinensis & Kacang panjang & Black-eyed pea & Horticulture & Leaf, Fruit & APNP \\
\hline Phaseolus radiatus & Kacang hijau & Green gram & Horticulture & Leaf, Fruit & APNP \\
\hline Abutilon crispum & Cemplak & Egyptian abutilon & Shrubs & Leaf & BNP \\
\hline Ocmum amaricanum & Selasih & American basil & Shrubs & Leaf & BNP \\
\hline Vernonia cinerea & Nyawonan & Purple fleabane & Shrubs & Leaf & BNP \\
\hline Thespesia lampas & Kapasan & Common mallow & Shrubs & Leaf & BNP \\
\hline Acalypha indica & Sangkep & Cat tail plant & Shrubs & Leaf, Flower, Seed & BNP \\
\hline Azima sarmentosa & Sokdoy & & Shrubs & Leaf, Flower, Seed & BNP \\
\hline Flemingia lineate ${ }^{* *}$ & Othok-othok & Large leaf eminia & Shrubs & Leaf, Flower, Seed & BNP \\
\hline Wisadula acidula & Rayutan & & Shrubs & Leaf, Flower, Seed & BNP \\
\hline Indigofera sumatrana & Tarum & Common indigo & Shrubs & Leaf, Flower, Seed & BNP \\
\hline Barleria prionitis & Berduri banyak & Porcupine flower & Shrubs & Leaf, Flower, Seed & BNP \\
\hline Callotropis giganthea & Widuri & Crown flower & Shrubs & Leaf, Flower, Seed & BNP \\
\hline Jasminum funale & Melati hutan & Jasmine & Shrubs & Leaf, Flower, Seed & BNP \\
\hline Morinda tinctoria & Mengkuduan & Indian mulberry & Tree & Fruit & BNP \\
\hline Zyzyphus rotundifolia & Bukol & Wild jujube & Tree & Fruit & BNP \\
\hline Glycosmis cochinchinensis & Jerukan & Citrus wild & Tree & Fruit & BNP \\
\hline Corypha utan & Gebang & Talipot palm & Palm & Fruit & BNP \\
\hline Streblus asper & Serut & Tootbrush tree & Tree & Fruit & BNP \\
\hline Ficus spp. & Beringin & Fig & Tree & Fruit & BNP \\
\hline
\end{tabular}

Notedt ${ }^{*}$ food species are prfered, ${ }^{* *}$ food species most are prfered 
stem; (d) Trees with leaves are not so dense, even dead trees with shaded leaves are used.

Vegetation analysis for roosting site in APNP was recorded at table 10 . The trees dominated at that area was randu alas (Bombax valetoni $=71.93 \%$ ), in pole stage was dominated by Apak (Ficus infectoria $=64.34 \%$ ), but timongo (Kleinhovia hospita) dominated at sapling stage. The important value index of trees surrounding roosting site was recorded at Table 10.

Chi-square test for number of trees was used as roosting at several types of habitat of BNP and APNP showed that number of roosting trees has significant different in both BNP and APNP, BNP $\left(\chi^{2}=61.87033\right.$, $\mathrm{P}<0.01)$, and APNP $\left(\chi^{2}=78.36756, \mathrm{P}<0.01\right)$.

\subsection{Sunning Site}

If the javan green peafowl get wet, they are sunning at place where the sun light direct to the bird. Usually the javan green peafowl is sunning at morning. The bird in BNP and APNP sunning at at tree, stamp pole or places direct with sun light. Besides sunning, the bird while is preening to make order the feathers. The duration of sunning of the javan green peafowl around 0.5-3 hour, depend on stge of wet and occurred the sun light. In general, the duration and frequency of sunning more frequent and longer done at rainy season compared dry season.

\subsection{Dusting Site}

The green peafowl select certain places for dusting on cram soil. Usually the places for dusting at open area which direct get sun. Usually dusting was done in morning 05.00-8.00 AM. Dusting activities held for manage the feathers and their skin from parasite. Dusting activities will be done only at dry season. The frequency of javan green peafowl dusting in APNP and BNP were recorded at Table 11.

Table 5. The javan green peafowl were encountered drink (frequencies) in Sadengan grazing area APNP and Bekol water reservoir BNP

\begin{tabular}{llcl}
\hline Activities & $\begin{array}{c}\text { Observation } \\
\text { time }\end{array}$ & $\begin{array}{c}\text { Frequency } \\
\text { (times) }\end{array}$ & \multicolumn{1}{c}{ Remark } \\
\hline Drinking & Morning & 140 & at puddle \\
in APNP & Afternoon & 40 & $\begin{array}{l}\text { Man made water } \\
\text { reservoir }\end{array}$ \\
\hline Drinking & Morning & 200 & $\begin{array}{l}\text { Bekol water reservoir } \\
\text { in BNP }\end{array}$ \\
Afternoon & 180 & Bekol water reservoir \\
\hline
\end{tabular}

Table 6. The javan green peafowl were encountered sheltering and resting (frequencies) in sadengan grazing area and intercropping of teak plantation of APNP and savanna, monsoon forest of BNP

\begin{tabular}{lccl}
\hline Activities & $\begin{array}{c}\text { Observation } \\
\text { time }\end{array}$ & $\begin{array}{c}\text { Frequency } \\
\text { (times) }\end{array}$ & \multicolumn{1}{c}{ Remark } \\
\hline $\begin{array}{l}\text { Shetering } \\
\text { and } \\
\text { resting }\end{array}$ & $09.30-13.00$ & 86 & $\begin{array}{l}\text { walikukun, } \\
\text { sonokeling laban, } \\
\text { apak, bambu, jati, } \\
\text { in APNP }\end{array}$ \\
$\begin{array}{l}\text { mahoni, herb and } \\
\text { shrub }\end{array}$ \\
$\begin{array}{l}\text { Shetering } \\
\text { resting } \\
\text { at BNP }\end{array}$ & $09.30-14.00$ & 125 & $\begin{array}{l}\text { widorobukol, } \\
\text { mimba, pilang, } \\
\text { asem, kesambi, } \\
\text { herb and shrub }\end{array}$ \\
\hline
\end{tabular}

Table 4. The frequency of the javan green peafowl were encountered feed in sadengan and grazing area intercropping area of APNP and savanna monsoon forest of BNP

\begin{tabular}{|c|c|c|c|}
\hline Activities & Kind of food & Frequency (times) & Remark \\
\hline Morning feeding & grasses and shrub & 240 & 05.30 AM - 9.30 AM in APNP \\
\hline Afternoon feeding & grasses and shrub & 240 & 14.00 PM - 17.30 PM in APNP \\
\hline Morning feeding & grasses and shrub & 240 & 05.30 AM - 9.30 AM in BNP \\
\hline Afternoon feeding & grasses and shrub & 240 & 14.00 PM - 17.30 PM in BNP \\
\hline
\end{tabular}

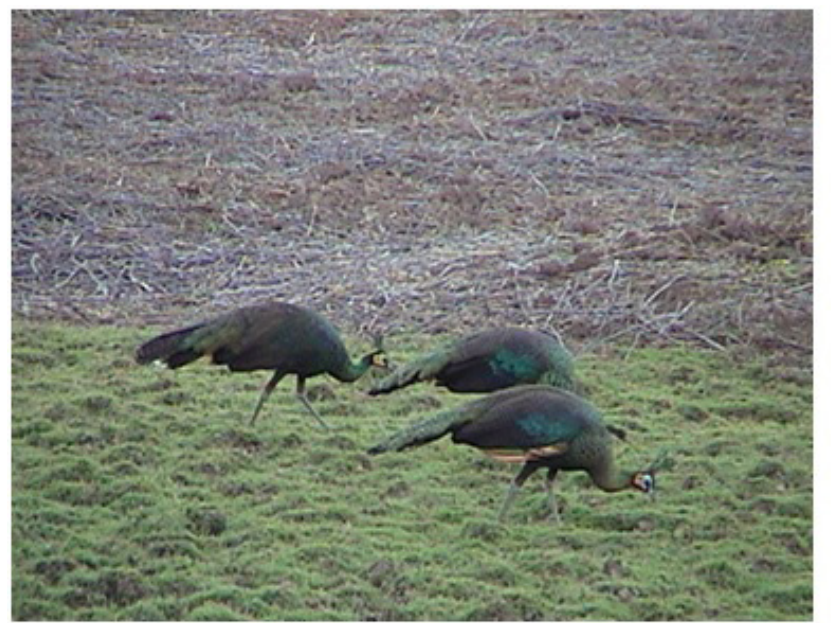

(a)

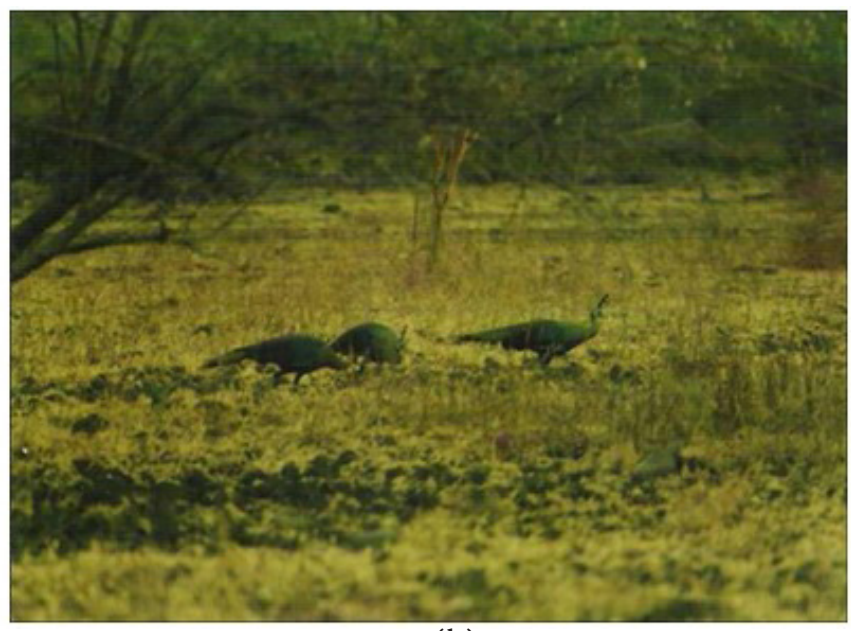

(b)

Figure 5. The javan green peafowl feed at (a) sadengan APNP (b) savanna BNP 


\subsection{Display Area}

Open areas which are relatively clean are preferred by peacocks during the mating season for dancing. Those activities for attracted the female bird. At Sadengan grazing area the peacock dance in middle of site or bellow shelter trees such as bungur (Lagerstroemia speciosa), walikukun (Schoutenia ovata) and laban (Vitex pubescens).

The frequency of javan green peafowl display in APNP and BNP were recorded at Table 12.

Besides, open areas at savanna and monsoon forest are chosen by the birds for dancing, but road Batangan - Bekol mainly at Hm 70 to HM 117 and Bekol - Bama HM 2-4, 12-21 BNP, also are preferred places for dancing. The dancing area where the adult male can gathering for dance was called Lek. The lek was found only Batangan - Bekol road of BNP. The male of the bird display in open area in APNP and BNP were shown at Figure 6.

\subsection{Nesting Site}

The green peafowl select area for the nest at open area which is growth by shrubs. Sunshine was direct to the eggs. The form of the nest is simple; form oval and the eggs are putted direct on the ground. The nest built with simple materials or did not contained materials. The green peafowl laid eggs varies 2-6 per nest, but mostly is $3-4$ eggs. has similar to (Hernowo 1995; Hernowo 1999; Hernowo et al. 2011b).

\subsection{Habitat Ideal of the Javan Green Peafowl}

Ideally the javan green peafowl habitat is habitats which meets with living need of the javan green peafowl is confort and save. Base on field observation in BNP and APNP, main diet of the javan green peafowl is kind species of grasses and shrubs. The grasses and shrubs species grow at open area which is not to large approximately $10-20$ ha. If the day became hot, the javan green peafowl will sheltere under luxuriant tree or at tree or at dense shrubs which is closed to the feeding site. The javan green peafowl select certaint tree for roosting site and near the tree present open area. The birds used shrubs area which sunshine get that place as nesting site. Forested area or dense shrubs used by the bird for covering site from many disturbances. The male of javan green peafowl select open area for dancing. Dusting activities done by the birds at open area which is the have dust soil. The javan green peafowl need continuously water

Table 8. The javan green peafowl roost in select trees (frequencies) in Sadengan and Intercropping area of APNP

\begin{tabular}{|c|c|c|c|}
\hline $\begin{array}{l}\text { Trees for } \\
\text { roost }\end{array}$ & $\begin{array}{l}\text { Local } \\
\text { name }\end{array}$ & $\begin{array}{l}\text { Frequency } \\
\text { (times) }\end{array}$ & Remark \\
\hline $\begin{array}{l}\text { Bombax } \\
\text { valetoni }\end{array}$ & $\begin{array}{l}\text { Randu } \\
\text { alas }\end{array}$ & 30 & $\begin{array}{l}16-19 \text { female, } \\
1 \text { male }\end{array}$ \\
\hline $\begin{array}{l}\text { Vitex } \\
\text { pubescens }\end{array}$ & Laban & 60 & 1 male \\
\hline Ficus elastica & Bendo & 60 & 2-6 female \\
\hline $\begin{array}{l}\text { Nauclea } \\
\text { siamea }\end{array}$ & Gempol & 8 & 2 female \\
\hline $\begin{array}{l}\text { Ficus } \\
\text { infectoria }\end{array}$ & Apak & 120 & 4 female \\
\hline $\begin{array}{l}\text { Syzigium } \\
\text { samarangense }\end{array}$ & $\begin{array}{l}\text { Jambu } \\
\text { hutan }\end{array}$ & 15 & 2 Female \\
\hline $\begin{array}{l}\text { Swietenia } \\
\text { macrophylla }\end{array}$ & Mahoni & 30 & $\begin{array}{l}2-4 \text { female/ } \\
\text { tree }\end{array}$ \\
\hline $\begin{array}{l}\text { Tectona } \\
\text { grandis }\end{array}$ & Jati & 90 & 1 male \\
\hline
\end{tabular}

Table 9. The javan green peafowl roost in select trees (frequencies) in Savanna of BNP

\begin{tabular}{lccl}
\hline \multicolumn{1}{c}{$\begin{array}{c}\text { Trees for } \\
\text { roost }\end{array}$} & $\begin{array}{c}\text { Local } \\
\text { name }\end{array}$ & $\begin{array}{c}\text { Frequency } \\
\text { (times) }\end{array}$ & \multicolumn{1}{c}{ Remark } \\
\hline $\begin{array}{l}\text { Acacia } \\
\text { leucophloea }\end{array}$ & Pilang & 180 & 1 male, 4 female \\
$\begin{array}{l}\text { Azedirachta } \\
\text { indica }\end{array}$ & Mimba & 90 & 1 male, 3 female \\
$\begin{array}{l}\text { Tamarindus } \\
\text { indica }\end{array}$ & Asem & 40 & 1 male \\
$\begin{array}{l}\text { Albizia } \\
\text { lebekkoides } \\
\begin{array}{l}\text { Corypha } \\
\text { utan }\end{array}\end{array}$ & Tekik & 25 & 1 male \\
\hline
\end{tabular}

Table 7. The javan green peafowl covering (frequencies) in APNP and BNP

\begin{tabular}{|c|c|c|c|c|}
\hline Activities & $\begin{array}{l}\text { Observation } \\
\quad \text { (times) }\end{array}$ & $\begin{array}{l}\text { Frequency } \\
\quad \text { (times) }\end{array}$ & Sources of disturbance & Remark \\
\hline $\begin{array}{l}\text { Covering } \\
\text { in APNP }\end{array}$ & $\begin{array}{l}\text { Morning } \\
\text { Afternoon }\end{array}$ & $\begin{array}{l}60 \\
30 \\
\end{array}$ & $\begin{array}{l}\text { Peoples, bird of prey } \\
\text { peoples }\end{array}$ & $\begin{array}{l}\text { walking, running to bush or fly to perch on } \\
\text { trees in sadengan and intercropping area }\end{array}$ \\
\hline $\begin{array}{l}\text { Covering } \\
\text { In BNP }\end{array}$ & $\begin{array}{l}\text { Morning } \\
\text { Afternoon }\end{array}$ & $\begin{array}{l}90 \\
60\end{array}$ & $\begin{array}{l}\text { peoples } \\
\text { peoples }\end{array}$ & $\begin{array}{l}\text { walking, running to bush or fly to perch on } \\
\text { trees in savanna, monsoon forest and side } \\
\text { road Bekol - Batangan }\end{array}$ \\
\hline
\end{tabular}


Table 10. Important Value Iindex (IVI) of trees at surround roosting site of the javan green peafowl in Sadengan APNP

\begin{tabular}{llcrcc}
\hline \multicolumn{1}{c}{ Trees species } & Local name & DR (\%) & FR (\%) & DoR (\%) & IVI (\%) \\
\hline Artocarpus elastica & Bendo & 6.67 & 9.09 & 33.88 & 49.64 \\
Strebulus asper & Serut & 26.67 & 18.18 & 3.38 & 48.23 \\
Ficus infectoria & Apak & 26.67 & 27.27 & 10.40 & 64.34 \\
Lagerstroemia speciosa & Ketangi & 13.33 & 18.18 & 1.91 & 33.42 \\
Dalbergia latifolia & Sonokeling & 6.67 & 9.09 & 0.34 & 16.10 \\
Bombax valetoni & Randu alas & 13.33 & 9.09 & 49.51 & 71.93 \\
Kleinhovia hospita & Timongo & 6.67 & 9.09 & 0.59 & 16.34 \\
\hline
\end{tabular}

Remark: DR = Density relative, FR = Frequency relative, DoR = Dominant relative, IVI = Important value index

Table 11. The frequency of javan green peafowl dusting in APNP and BNP

\begin{tabular}{lccl}
\hline Activities & $\begin{array}{c}\text { Observation } \\
\text { time }\end{array}$ & $\begin{array}{c}\text { Frequency } \\
\text { (times) }\end{array}$ & \multicolumn{1}{c}{ Remark } \\
\hline $\begin{array}{l}\text { Dusting } \\
\text { at APNP }\end{array}$ & Morning & 24 & $\begin{array}{l}\text { Open area at } \\
\text { sadengan and } \\
\text { intercropping } \\
\text { area }\end{array}$ \\
\hline Dusting & Morning & 30 & $\begin{array}{l}\text { Open area } \\
\text { at savanna } \\
\text { at BNP }\end{array}$ \\
& & $\begin{array}{l}\text { Bekol, side } \\
\text { road HM 100 } \\
\end{array}$ & \\
& & 110 Bekol - \\
& & Batangan \\
\hline
\end{tabular}

Table 12. The frequency of javan green peafowl were encountered display in APNP and BNP

\begin{tabular}{lccl}
\hline Activities & $\begin{array}{c}\text { Observation } \\
\text { time }\end{array}$ & $\begin{array}{c}\text { Frequency } \\
\text { (times) }\end{array}$ & \multicolumn{1}{c}{ Remark } \\
\hline & & $\begin{array}{l}\text { Open area, } \\
\text { under shelter } \\
\text { tree, at }\end{array}$ \\
& Morning & 86 & $\begin{array}{l}\text { sadengan and } \\
\text { intercropping } \\
\text { area }\end{array}$ \\
Display & & & Open area, \\
at APNP & & & under shelter \\
& & & tree, at \\
& & & sadengan and \\
intercropping & area
\end{tabular}

\section{Open area,} under shelter tree, at savanna, monsoon forest, Morning 116 road BatanganBekol Hm 70-

Display at BNP
117, Bekol-Bama

$\mathrm{Hm}$ 2-4, Hm

$12-21$

Open area, under shelter tree, road Afternoon $54 \quad$ Batangan-Bekol Hm 70-117, Bekol-Bama Hm 2-4, Hm 12-21
Table 13. Ideally habitat component of the javan green peafowl

\begin{tabular}{|c|c|}
\hline Habitat function & $\begin{array}{c}\text { Characteristic of habitat compenet, } \\
\text { availability and enough }\end{array}$ \\
\hline Feeding & $\begin{array}{l}\text { Kind species of grasses and shrubs in } \\
\text { open area as gaps with minimum not } \\
\text { less than } 1 \text { ha }\end{array}$ \\
\hline Drinking & water (continously) \\
\hline $\begin{array}{l}\text { Sheltering and } \\
\text { resting }\end{array}$ & $\begin{array}{l}\text { Tree with luxuriant leave in open area } \\
\text { or closed to open area }\end{array}$ \\
\hline covering & $\begin{array}{l}\text { Group of tree or forested area, or dense } \\
\text { shrubs }\end{array}$ \\
\hline Roosting & $\begin{array}{l}\text { Emergent tree, rare leave, or shaded } \\
\text { leave }\end{array}$ \\
\hline Dancing & Open area and clean, gaps or road \\
\hline Nesting & $\begin{array}{l}\text { Open area where the sun direct to the } \\
\text { place, shrubs area }\end{array}$ \\
\hline Sunn & Open area, at the tree get direct sun \\
\hline Dus & Dusting area \\
\hline
\end{tabular}

resources. The habitat component for ideally habitat of the javan green peafowl as shown at Table 13 .

Over all habitat gradient such as open area which is growed by grasses and shrubs for searching food (feeding site), places where water resources available (drinking site), tree or shaded places for sheltering and resting (sheltering and resting site), tree, forest or dense shrubs for covering tempat (covering site), tree for sunning (sunning site), dust places (dusting site), open area for dancing (dancing area) and open area which is growed by shrubs as nested places (nesting site) were compound (synthesis) became one site with lay out as Figure 7 with quantity and quality of habitat component are adequate become ideally habitat for javan green peafowl.

\section{Discussion}

\subsection{Feeding Site}

Characteristic of javan green peafowl feeding site is open area, which are growth by grasses and few of shrubs and be surrounded by tree. The open area is performing such as grazing area, intercropping area, savanna and forest gaps minimum large area approximately 1 ha. The javan peafowl search food on open area (Ponsena 1988; Hernowo 1995; Hernowo 1999; Hernowo and Hernawan 2003; Hernowo and 


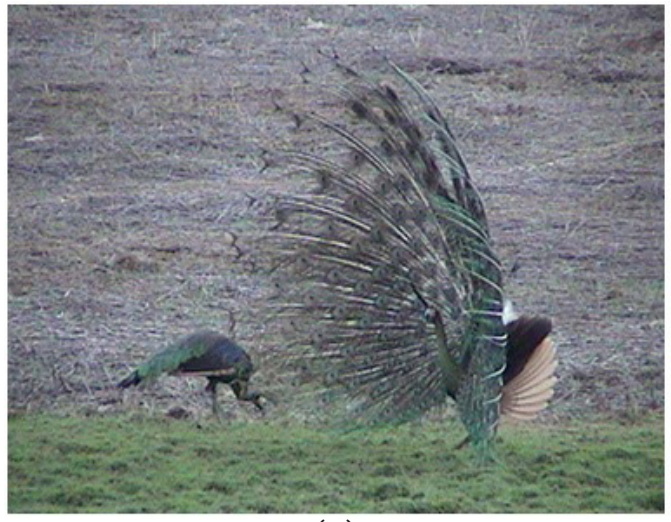

(a)

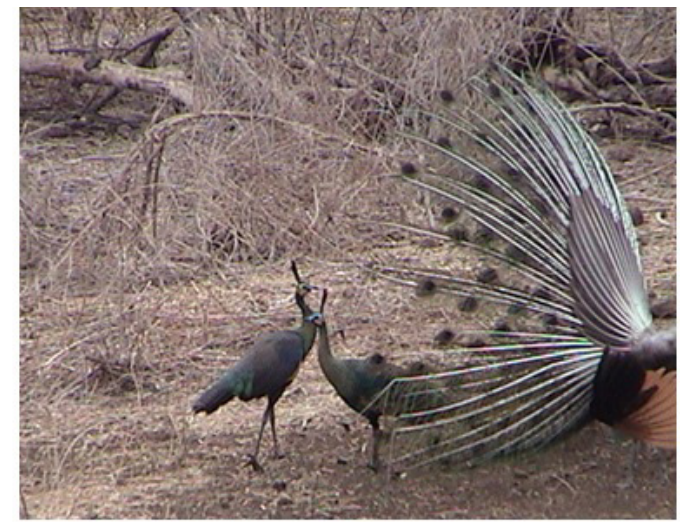

(b)

Figure 6. Male display at open area (a) Sadengan APNP (b) Bekol BNP

Sketch of the javan green peafowl idealy habitat
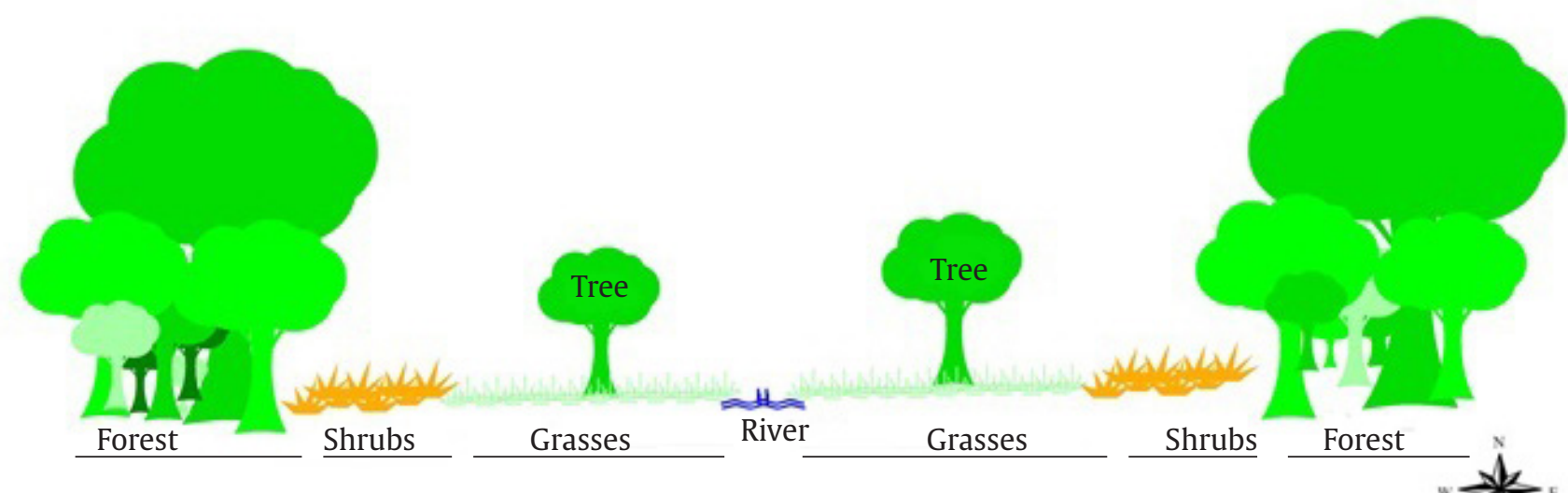

Grasses

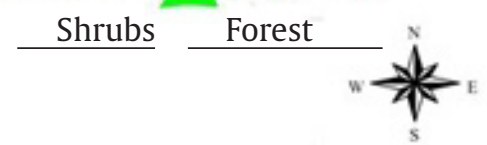

Upper sketch of the javan green peafowl idealy habitat

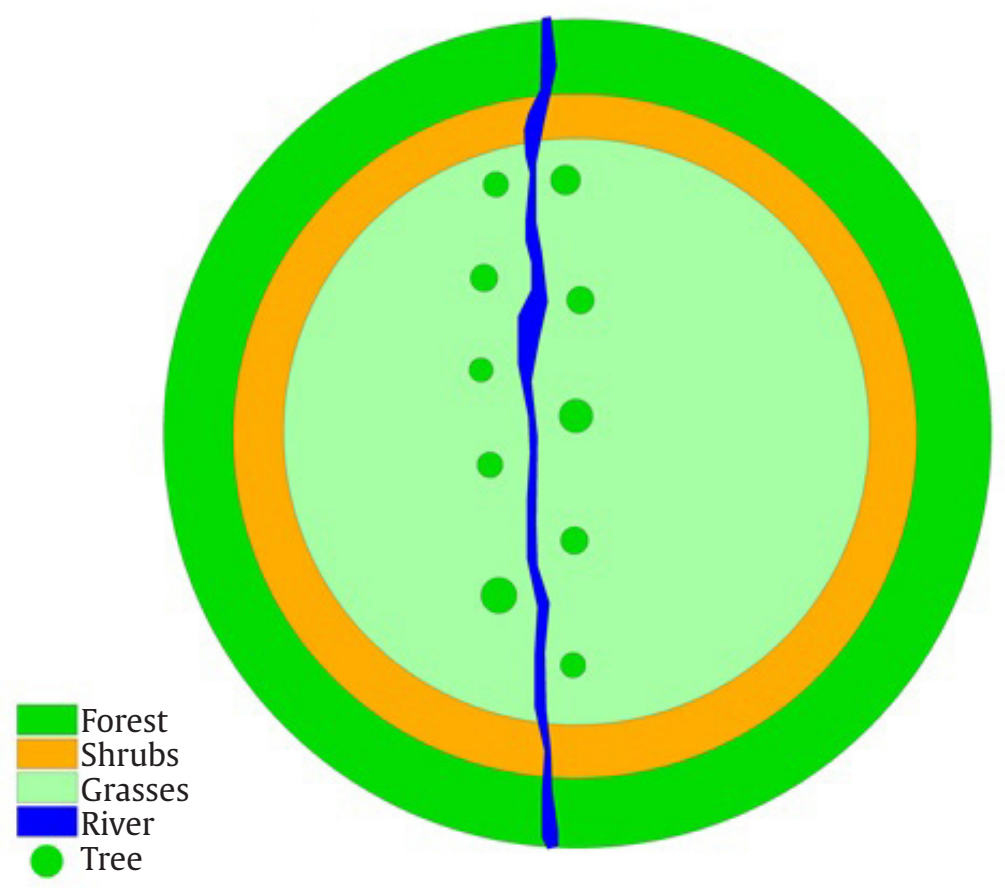

Figure 7. The sketch of ideally habitat of the javan green peafowl 
Palita 2004; Rini 2005; Hernowo and Wasono 2006; Yuniar 2007; Risnawati 2008). Leaf and fruit or seed of grass and shrubs are main diet for green peafowl. 19 species of grasses and 16 shrubs also 6 species of horticulture and 5 of fruit trees species were eaten by green peafowl in APNP and BNP. The green peafowl feed on leaf, flower and seeds of the grasses and shrubs. The javan green peafowl feed on quite wide range species of grasses and shrubs (Rini 2005; Septania 2009). The bird is as omnivorous species quite demanding on food, because they size quite big. To get enough diet they explore many kind of food. The green peafowl ecological strategic search food more on vegetation and they do while working (Hernowo 2011). The open area which is growed by grasses and shrubs and surrounded by forest is important as habitat component for javan green peafowl.

\subsection{Drinking Site}

Drinking site of javan green peafowl does not have characteristic. The important for drinking site is continous available water and not salt and clean. During dry season water is limited in certain places. The birds will come to drink at drinking places every day. Availability of continued water resources is important for living of the green peafowl (Hernowo 2011). During dry season the javan peafowl gathering closed to water reasources at Bekol water hole in BNP or at Sadengan grazing area (Hernowo 1995; Yuniar 2007; Risnawati 2008). The green peafowl gathering closed water resources and the bird densities have relation to water resources (Ponsena 1988; Brickle 2002; Hernowo 2011). The individual abundance of green peafowl in Dak Lak Province, Vietnam more abundance closed to the river bank (Brickle 2002). Ponsena 1988, stated that individual number of green peafowl Huai Kang Khaeng Wildlife Sanctuary more abundance at riparian area.

\subsection{Sheltering Site}

The javan green peafowl sheltered and take rest at trees or under luxuriant tree as characteristic resting site and the selected trees do not far from feeding site (Hernowo 2011). The resting trees at Baluran were widoro bukol, pilang, asem, kesambi, and mimba (Mulyana 1988; Hernowo 1995; Yuniar 2006; Risnawati 2008). Meanwhile in TNAP the birds used walikukun, laban, sonokeling, apak serta jati as sheltered trees (Hernowo and Wasono 2006; Yuniar 2006; Risnawati 2008). The sheltering site used by the bids were not far from feeding site in BNP and APNP (Hernowo 2011).

\subsection{Roosting Site}

The green peafowl slept on tree (Ponsena 1988; Hernowo 1999). According to Hernowo 1999, the green peafowl select certain tree for roosting site. The characteristic of roosting tree is tall tree (emergent tree), not dense leaft, branching system up right angle to the stem and present open area closing to roosting tree. Most preferred roosting trees at BNP were pilang and dead of gebang (Hernowo 1995; Yuniar 2006; Risnawati 2008), meanwhile at APNP preffered trees as roosting site was Apak (Hernowo and Wasono 2006; Yuniar 2006; Risnawati 2008; Hernowo 2011). Subramanian and John (2001) reported that the Indian blue peafowl (Pavo cristatus) at Reserve forest of Deer Park, Tirunevelvi Tamil Nadu preffered roosted on tamarind (Tamarindus indicus), vagai (Albizia lebbeck), neem (Azadirachta indica), usilai (Albizia amara), and palmyra (Borrassus flabellifer) also less frequently on manjanathi (Morinda tenctoria) and velvelam (Acacia leucophloea). At Vivekananda Kendra, the bird prefer roost at coconut palm (Cocos nucifera) primarily used for roost, while tamarind, neem, manggo (Mangifera indica) and umbrella thorn (Acacia planifrons) to be second choise. Even telecommunication pylons are used as roost site.

\subsection{Display Area}

Displays conducted by the male of green peafowl at open area such as grazing area, intercropping area, savanna and gaps (Hernowo 1999; Hernowo and Wasono 2006; Yuniar 2007; Risnawati 2008; Hernowo 2011). Those preferred places are selected because easily for the female bird found the male and for male bird can dance more easily (Hernowo 2011; Hernowo et al. 2011b).

\subsection{Nesting Site}

Nesting site of green peafowl is open area which is growth by shrubs (Hernowo 1999; Hernowo and Hernawan 2003). Sometimes the nest direct get sun when do not occupied by female birds (Hernowo 1995; Hernowo and Hernawan 2003). The nest performace is very simple and the egg direct contact with soil. Direct contacts with soil or sun are helping on hatching of the eggs (Hernowo 2011).

\subsection{Habitat Prefference}

In relation to habitat preferences, the birds more distribute at savanna in BNP or intercropping area of teak plantation and grazing ground in APNP because the habitat contain many of open area (Hernowo et al. 2011a). They feed in particularly much kind of grasses and shrubs where it is much grow at the open area. The abundances of the bird have relation to abundances of food habitat. At forest habitat where present open area growing grasses and shrubs, the green peafowl will abundance. The emergent trees not dense leave and up right branch where growths near open area are preferred as roosting tree. Availability of water resources continuously is one of important habitat factor for living the javan green peafowl. Forested area where present open areas which are growing by grasses and shrubs, also close to continuously water resources is ideally habitat for the javan green peafowl (Hernowo 2011). 


\subsection{Ideally Javn Green Peafowl Habitat}

The characteristic habitat of javan green peafowl is open area which is surrounded by forest. The green peafowl are searching food more at open area as feeding site. The green peafowl as omnivorous bird and ground animal feed much on leaf, seed of grasses and leaf and fruit of shrubs. They are choosing luxuriant tree or shady place for sheltering during the hot days. The birds select certain tree as tall tree or emergent tree for roosting and not for the tree there any open area. Nesting site of the bird is open area where shrubs are growing. The javan green peafowl prefer habitat such as savanna, grazing area surrounded by forest and intercropping teak forest plantation. The ideally habitat of the javan green peafowl is open area not so large which is growth by grasses and shrubs and it's surrounded by forest and closed to water resources (continuously of the availability), occurred shelter site (luxuriant tree), cover site (forest or dense shrubs), roost site (tall trees, not so dense leaf and have up right branch system) closed to open area, present dusting places, have nest site (open area which is growth shrubs). Those habitat component combined became one.

\section{Refferences}

Brickle NW. 2002. Habitat use, predicted distribution and conservation of green peafowl (Pavo muticus) in Dak Lak Province, Vietnam. Biological Conservation Journal 105:189-197.

Collar NJ, Andrew P. 1988. Birds to watch. Cambridge: ICBP tech. Publication 8.

Hernowo JB. 1995. Ecology and behaviour of the green peafowl (Pavo muticus Linnaeus 1766) in the Baluran national park. East Java, Indonesia [Thesis]. GÖttingen:Faculty of Forestry Science, Goerg August University.

Hernowo JB. 1999. Habitat and local distribution of javan green peafowl (Pavo muticus muticus Linnaeus 1758) in Baluran national park, East Java. Media Konservasii VI:15- 22.

Hernowo JB, Hernawan E. 2003. Population and habitat study of javan green peafowl ( Pavo muticus muticus Linnaeus 1758 ) at Ciawitali teak forest plantation of BKPH Buahdua and BKPH Songgom, KPH Sumedang. Media Konservasi VIII:117-126.

Hernowo JB, Palita Y. 2004. Study on local distribution and behaviour of javan green peafowl (Pavo muticus muticus Linnaeus 1758) at Meru Betiri national Park. Media Konservasi IX:69-76.

Hernowo JB, Wasono WT. 2006. Population and habitat of javan green peafowl (Pavo muticus muticus Linnaeus 1758 ) at Alas Purwo national park. Media Konservasi $\mathrm{XI}: 83-88$.

Hernowo JB. 2011. Ecology of the javan green peafowl (Pavo muticus muticus) Linnaeus 1758 at several habitat types in eastern tip of their distribution East Java, Indonesia [Dissertation]. Bogor:Forestry science study programme. Post Graduate School, Bogor Agricultural University.
Hernowo JB et al. 2011a. Population analysis of javan green peafowl (Pavo muticus muticus Linnaeus 1758) in Baluran and Alas Purwo national park, East Java. Biodiversitas 12:99-106.

Hernowo JB et al. 2011b. Behavior ecology of the javan green peafowl (Pavo muticus muticus Linnaeus 1758) in Baluran and Alas Purwo national park, East Java. HAYATI Journal of Biosciences 18:164-176.

Mueller-Dumbois D, Ellenberg H. 1974. Aims and methods of vegetation ecology. New York:John Wiley \& Sons.

Mulyana. 1988. Habitat study of Green Peafowl in Bekol Resort of Baluran National Park [Thesis]. Bogor: Department of Forest Resources Conservation, Faculty of Forestry. Bogor Agricultural University.

Ponsena P. 1988. Biological characteristic and breeding behaviours of green peafowl (Pavo muticus Linnaeus) in Huai Kha khaeng Wildlife Sanctuary. Thai J For 7:303-313.

Rini IS. 2005. Feeding ecology and feeding behavior of green peafowl (Pavo muticus Linnaeus 1766) in Alas Purwo National Park, East Java [Thesis]. Bogor:Department Forest Resources Conservation and Ecotourism, Faculty of Forestry, Bogor Agricultural University.

Risnawati R. 2008. Population and Habitat Analysis of Green Peafowl (Pavo muticus Linnaeus, 1766) at Alas Purwo and Baluran National Park, East Java [Thesis]. Bogor:Department Forest Resources Conservation and Ecotourism, Faculty of Forestry, Bogor Agricultural University.

Septania KA. 2009. Potential plants as food of javan green peafowl (Pavo muticus muticus Linnaeus 1758) at Baluran national park East Java [Thesis]. Bogor:Bogor Agricultural University Post Graduate School.

Setiadi AP. 1994. Habitat study of breeding site of javan green peafowl (Pavo muticus muticus Linnaeus, 1766) in Resort Bekol of Baluran national park, East Java [Thesis]. Bandung:Padjadjaran University.

Setiawan I. 1994. Pattern of roosting site and social relation ship G. Ringgit Pasir Putih, East Java [Thesis]. Bandung:Padjadjaran University.

Subramanian KS, John MC. 2001. Rosting and nesting habits of free ranging indian peafowl (Pavo cristatus) in Southern Tamil Nadu. Zoos' Print Jurnal 16:537-538.

Takandjandji M, Sawitri R. 2011. Populasi Burung Merak Hijau (Pavo muticus Linnaeus, 1766) di ekosistem savana, Taman Nasional Baluran, Jawa Timur. Jurnal Penelitian dan Konservasi Alam 8:13-24.

van Balen S et al. 1995 The distribution and status of green peafowl In Java. Biol Conserv J 71:289-297.

Yuniar A. 2007. Population and habitat study of green peafowl (Pavo muticus Linnaeus 1766), in Alas Purwo and Baluran national park, East Java [Thesis]. Bogor:Department Forest Resources Conservation and Ecotourism, Faculty of Forestry, Bogor Agricultural University. 